International Journal of Current Microbiology and Applied Sciences

ISSN: 2319-7706 Volume 6 Number 7 (2017) pp. 97-101

Journal homepage: http://www.ijcmas.com

Original Research Article

https://doi.org/10.20546/ijcmas.2017.607.011

\title{
Entrepreneurial Behaviour of Dairy Farmers: A Study in Marathwada
} Region of Maharashtra, India

\author{
Satish M. Sadashive ${ }^{1}$, Santosh S. Pathade², Manish N. Sawant ${ }^{2}$, \\ N. Ramesh $^{3}$ and K. I. Pordhiya ${ }^{4}$ \\ ${ }^{1}$ National Dairy Research Institute, Karnal, Haryana, India \\ ${ }^{2}$ Department of Veterinary and Animal Husbandry Extension, Bombay Veterinary College, \\ Mumbai, Maharashtra-400012, India \\ ${ }^{3}$ IVRI, Izzatnagar, Bareilly, UP-243122, India \\ ${ }^{4}$ LUVAS, Hisar, Haryana, India \\ *Corresponding author
}

\section{A B S T R A C T}

\section{Keywords \\ Dairy farmers, \\ Entrepreneurial \\ behaviour, \\ Entrepreneurship, \\ Dairy sector. \\ Article Info \\ Accepted: \\ 04 June 2017 \\ Available Online: \\ 10 July 2017}

A study was conducted in Aurangabad and Jalna district of Marathwada region of Maharashtra to know the level of entrepreneurial behaviour of dairy farmers. A sample of 120 respondents was selected for present study. The nine components of behaviour were undertaken to evaluate the status of entrepreneurial behaviour such as, innovativeness, achievement motivation, decision-making ability, risk-orientation, information-seeking behaviour, Cosmo politeness, self-confidence, economic motivation and management orientation. The results revealed that majority of the respondents possessed medium level $(68.33 \%)$ followed by low $(17.50 \%)$ and high level (14.17\%) of entrepreneurial behaviour.

\section{Introduction}

Entrepreneurship development in India has enormous potential in terms of diversity of rural occupations. Dairy farming is not an indispensable component of agriculture, but also the most suitable production system that can be the act as tool for improving the socioeconomic status of the rural population. Thus, entrepreneurial development is one of the ways to make rural people more competent in dairying as well as youth can be engaged in the agriculture by generating employment. Dynamic entrepreneurs are considered to be the agent of change in a society.
Entrepreneurs play a very important role in generating new employment and setting up new business. Therefore keeping in view the importance of the entrepreneurship and prospects in dairy sector in India, there is needed to harness the potential of dairy farmers. So that the, alternate strategy can be suggested to concerned government and department for providing information and knowledge to the rural masses for enriching the entrepreneurship development among them. 


\section{Materials and Methods}

The present study was conducted in the Marathwada region of Maharashtra because NABARD has implemented the Dairy Entrepreneurship Development Scheme in the various regions of Maharashtra especially in the Marathwada and Vidarbha region since 2004. Out of eight district of Marathwada region Aurangabad and Jalna district were selected randomly, further two tahsil from each selected districts and two villages from each tahsil were selected randomly. From each selected village, 15 dairy entrepreneurs were selected randomly. Thus a total of 120 dairy entrepreneurs were covered under the study.

The entrepreneurial behaviour of dairy farmers was measured in terms of nine dimensions namely, innovativeness, achievement motivation, decision-making ability, risk-orientation, information-seeking behaviour, Cosmopoliteness, self-confidence, economic motivation and management orientation. The scale developed by Chaudhari (2007) used to measure first seven dimensions and Supe and Singh (1969) for last two dimensions.

\section{Results and Discussion}

The most of the dairy farmers $(68.33 \%)$ had medium level, followed by low (17.50\%) and high level $(14.17 \%)$ of entrepreneurial behaviour. Similar finding were reported by Chandramouli et al., (2007), Subrahmanyeswari et al., (2007) and Ram et al., (2014).

\section{Components of entrepreneurial behaviour of dairy farmers}

Nine components of entrepreneurial behaviour of the farmers were measured and the result is presented in table 2 as fallows.

\section{Innovativeness}

Majority of respondents had medium level $(75.83 \%)$, whereas $(19.17 \%)$ dairy farmers belonged to low while remaining 5.00 per cent dairy farmers belonged to high innovativeness category. The results were in line with Pal (2006). The possible reasons might be due to middle level education, small and marginal land holding and medium information seeking behaviour of dairy farmers.

\section{Achievement motivation}

It is apparent from table 2 that $(70.00 \%)$ dairy farmers had medium, whereas $(15.83 \%)$ dairy farmers belonged to low, followed by 14.17 per cent belonged to high achievement motivation category. The findings were similar to the results of Nagesha (2005).The medium level of achievement motivation among dairy farmers might be due to their enthusiasm to become economically sound.

\section{Decision-making ability}

It represents from table 2 that $(49.17 \%)$ dairy farmers had medium, whereas $(26.67 \%)$ had lower followed by $(24.16 \%)$ dairy farmers had high decision making ability.

This might be due to their middle followed by higher level of education. Decision making ability is based on the foresight and confidence of an individual.

\section{Risk-orientation}

It is evident from table 2 that (44.17\%) dairy farmers were having medium, whereas $(37.50$ $\%)$ were having low followed by $(18.33 \%)$ dairy farmers were having high risk orientation. It might be due to inability of dairy farmers under small and marginal land holding category to face risk, as they were not 
financially sound as compared to economically sound dairy farmers.

\section{Information-seeking behaviour}

Nearly about half (49.17\%) of dairy farmers had medium; whereas (31.67\%) had low followed by 19.16 per cent dairy farmers with higher level of information seeking behavior. The plausible reasons for majority of dairy farmers under medium category of information seeking behaviour might be due to the fact that their middle level of education, medium interest and low exposure of improved dairy technologies.

Table.1 Distribution of respondents on the basis of their overall entrepreneurial behaviour

\begin{tabular}{|l|l|l|l|}
\multicolumn{4}{|c|}{$(\mathrm{n}=120)$} \\
\hline Sl. no. & Category & Frequency & Percent \\
\hline 1 & Low & 21 & 17.50 \\
\hline 2 & Medium & 82 & 68.33 \\
\hline 3 & High & 17 & 14.17 \\
\hline
\end{tabular}

Table.2 Distribution of dairy farmers based on components of entrepreneurial behaviour of dairy farmers

\begin{tabular}{|c|c|c|c|c|}
\hline Sl. No. & Variables & Categories & Frequency & Percent \\
\hline \multirow{3}{*}{1.} & \multirow{3}{*}{ Innovativeness } & Low & 23 & 19.17 \\
\hline & & Medium & 91 & 75.83 \\
\hline & & High & 6 & 5.00 \\
\hline \multirow{3}{*}{2.} & \multirow{3}{*}{$\begin{array}{l}\text { Achievement } \\
\text { Motivation }\end{array}$} & Low & 19 & 15.83 \\
\hline & & Medium & 84 & 70.00 \\
\hline & & High & 17 & 14.17 \\
\hline \multirow{3}{*}{3.} & \multirow{3}{*}{$\begin{array}{l}\text { Decision Making } \\
\text { Ability }\end{array}$} & Low & 32 & 26.67 \\
\hline & & Medium & 59 & 49.17 \\
\hline & & High & 29 & 24.16 \\
\hline \multirow{3}{*}{4.} & \multirow{3}{*}{ Risk Orientation } & Low & 45 & 37.50 \\
\hline & & Medium & 53 & 44.17 \\
\hline & & High & 22 & 18.33 \\
\hline \multirow{3}{*}{5.} & \multirow{3}{*}{$\begin{array}{l}\text { Information } \\
\text { Seeking Behaviour }\end{array}$} & Low & 38 & 31.67 \\
\hline & & Medium & 59 & 49.17 \\
\hline & & High & 23 & 19.16 \\
\hline \multirow{3}{*}{6.} & \multirow{3}{*}{ Cosmopoliteness } & Low & 38 & 31.67 \\
\hline & & Medium & 53 & 44.17 \\
\hline & & High & 29 & 24.16 \\
\hline \multirow{3}{*}{7.} & \multirow{3}{*}{ Self Confidence } & Low & 27 & 22.50 \\
\hline & & Medium & 71 & 59.17 \\
\hline & & High & 22 & 18.33 \\
\hline \multirow{3}{*}{8.} & \multirow{3}{*}{$\begin{array}{l}\text { Economic } \\
\text { Motivation }\end{array}$} & Low & 26 & 21.67 \\
\hline & & Medium & 39 & 32.50 \\
\hline & & High & 55 & 45.83 \\
\hline \multirow{3}{*}{9.} & \multirow{3}{*}{$\begin{array}{l}\text { Management } \\
\text { Orientation }\end{array}$} & Low & 51 & 42.50 \\
\hline & & Medium & 46 & 38.33 \\
\hline & & High & 23 & 19.17 \\
\hline
\end{tabular}




\section{Cosmo politeness}

(44.17) per cent dairy farmers had a medium level; whereas $(31.67 \%)$ had low followed by 24.16 per cent dairy farmers had high level of Cosmo politeness. As per the above results, considerable percentage of dairy farmers had medium Cosmo politeness. This might be due to their low economic conditions, thereby less active participation in extension activities like field visits, cattle exhibitions, krishi mela and also due to their less extension contact with veterinary doctors, livestock inspectors and dairy entrepreneurs.

\section{Self-confidence}

It is quite clear from table 2 that $(59.17 \%)$ of dairy farmer had medium; whereas $(22.50 \%)$ had low followed by $(18.33 \%)$ dairy farmers had high self-confidence. The dairy farmers were not enough confident about their abilities to improve their dairy enterprise and were not so much success for running dairy enterprise. This may be the reason of medium self-confidence.

\section{Economic motivation}

Majority (45.83\%) dairy farmers had high, whereas $(32.50 \%)$ dairy farmers had medium, followed by 21.67 per cent had low economic motivation. The similar findings were reported by, Khin Mar Oo (2005). The reason for high economic motivation of dairy farmers might be due to getting daily cash in hands which raise the purchasing power of dairy farmers from dairy enterprise. Dairy farmers were highly motivated economically in majority for their liveliness.

\section{Management orientation}

Less than half (45.50\%) of dairy farmers had low, whereas $(38.33 \%$ ) had medium followed by 19.17 per cent dairy farmers had low management orientation. Similar results were noted by Hanchial (1999). The probable reason for low scientific orientation might be due to their varied education levels, small \& marginal land holding and low income from dairying.

This paper examined the underlying construct "entrepreneurial behaviour" of dairy farmers in Marathwada region of Maharashtra state. The study has clearly shown that majority of the farmers had a medium level of entrepreneurial behaviour.

Nearly half of the respondents had medium level of innovativeness and more than half of the respondents had medium level of achievement motivation, decision making ability, risk orientation, information seeking behaviour, self-confidence and Cosmo politeness. In terms of managementorientation, it was found to be low to medium levels.

Finally, it can be concluded that, the dairy farmers had high economic motivation to adopt new agriculture cum dairy technologies to increase their income and thereby enhancing their standard of living. Therefore, efforts should be made to increase the level of entrepreneurial behaviour through entrepreneurship awareness, intensive training programmes, group discussions, demonstrations, tours, field visits etc., for socio economic upliftment of the dairy farmers.

\section{Acknowledgement}

I am thankful to dairy Farmers, Co-operative society members and DRDA (District Rural Development Agency) officials who cooperate very kindly and affectionately during collection of data. I also like to acknowledge journal editor and reviewers who helped me in research paper. 


\section{References}

Chandramouli, P., Meti, S. K., Hirevenkanagoudar, L. V. and Hanchinal, S. N. 2007. Comparative analysis of entrepreneurial behavior of farmers in irrigated and dry land areas of Raichur district of Karnataka. Karnataka J. Agril. Sc., 20 (2): 320-321.

Chaudhari, R. R., Hirevenkanagoudar, L. V., Hanchinal, S. N. and Mokashi, A.N. 2007. A scale for measurement of entrepreneurial behavior of dairy farmers. Karnataka J. Agril. Sc, 20 (4): 792-796.

Hanchinal, S. N. 1999. Privatization of extension service: attitude and preference of farmers and extension personnel. Ph. D. Thesis, University of Agricultural Sciences, Dharwad.

Khin Mar Oo. 2005. Knowledge and adoption of improved dairy management practices by women dairy farmers in Dharwad district. M. Sc. Thesis, University of Agricultural Sciences, Dharwad.
Nagesha, 2005. Study on entrepreneurial behaviour of vegetable seed producing farmers in Haveri district of Karnataka. M. Sc. (Agri.) Thesis, University of Agricultural Sciences, Dharwad.

Pal, S. 2006. Study on dairy livestock feeding and health care practices among dairy entrepreneurs in Burdwan district of West Bengal. M.Sc. Thesis, NDRI Deemed University, Karnal (India).

Ram, D., Margaret N. and Singh, M.K. 2014. Entrepreneurial behavior of farmers in Imphal district of Manipur. Indian Journal of Extension Education, 50(1 \& 2): 4-7.

Subrahmanyeswari, B., Veeraraghava, R. K. and Sudhakar, R. B. 2007. Entrepreneurial behaviour of rural women farmers in dairying: A multidimensional analysis. Livestock research for rural development, 19(15).

Supe, S. V. and Singh, S. N. 1969. Dynamics of rational behaviour of Indian farmers. New Heights Publishers and distributors, New Delhi.

\section{How to cite this article:}

Satish M. Sadashive, Santosh S. Pathade, Manish N. Sawant, N. Ramesh and Pordhiya, K.I. 2017. Entrepreneurial Behaviour of Dairy Farmers: A Study in Marathwada Region of Maharashtra. Int.J.Curr.Microbiol.App.Sci. 6(7): 97-101. doi: https://doi.org/10.20546/ijcmas.2017.607.011 